\title{
Online Learning Implementation in the Covid-19 Pandemic
}

\author{
Siska Andes Madya ${ }^{*}$ Abdurahman $^{1}$ \\ ${ }^{1}$ Indonesian Language and Literature Education, FBS Padang State University, Padang, West Sumatra 25131 \\ *Corresponding author. E-mail: andesmadya.siska@gmail.com
}

\begin{abstract}
The Indonesian government enforces online learning at all levels of education to prevent the spread of Covid19. Changing learning patterns will affect the implementation of learning. This study aims to review the implementation of online learning during the Covid-19 Pandemic emergency in Indonesia. This research is a descriptive study. Data collection techniques is the study of literature by collecting various articles, books, and documents lai $\mathrm{n}$ its own topic of perception in learning online, learning applications used in online, and learning strategies online. The data collected is grouped and analyzed in order to get a conclusion. The online learning system can be implemented effectively. However, various challenges and unpreparedness in online learning remain. Applications that can be used in online learning include Rumah Belajar, Meja Kita, Icando, IndonesiaX, Google for education such as Google form, Google Meeting, and Google Classroom, Microsoff Office 365, Quipper School, Ruang Guru, Sekolahmu, Zenius, Cisco Webex, Whatsapp, Edmodo, Zoom, and Quizizz. The applications that are widely used are Whatsapp, Google Classroom, and Zoom. Online learning strategies can be done with creative and innovative learning methods, simple, and utilizing various learning applications.
\end{abstract}

Keywords: online, implementation, dynamics, solutions, covid-19

\section{INTRODUCTION}

Indonesian education experienced various problems during Covid-19 pandemic. The social impact of distancing has a big influence on the implementation of learning. The conditions during the Covid-19 pandemic were called special conditions so that the implementation of learning was also carried out in a different way, namely Distance Learning. Distance learning is carried out based on the circular of the Minister of Education and Culture number 4 of 2020 concerning the implementation of education policies in an emergency of the spread of the virus [1].

Distance learning is a big challenge for teachers and students in implementing learning. Learning is implemented in two ways, namely online and offline [2]. Online learning can be defined as e-learning. Online learning is carried out using a network or online while learning outside the network without using a network. This means that through online learning during the Covid-19 pandemic, teachers and students can master science and technology. Mastery of technology is one of the $21 \mathrm{st}$ century thinking frameworks in Indonesia. Ariyana, et al. [3] explains that 21st century thinking concepts that will be applied in basic education include: (1) creativity thinking and innovation, (2) critical thinking and problem solving, (3) communication and colaboration; (4) information, media, and technology skills; (5) life and career skills, namely character building and spiritual values.
Online learning is not a new model in Indonesia. Several studies on the implementation of online learning at the elementary school level have been carried out. Online learning has a positive impact and shows high student motivation [4]. In addition, by using Edmodo app in learning online have a significant influence on student learning outcomes in natural science subjects compared to the conventional learning. Online learning is considered effective and efficient as it can be done anywhere and anytime with HP, androids, laptop, or computer [5]. Online learning during the pandemic Covid-19 need to get the attention of some aspects such as how to practice, what applications are used, and what strategies do that learning can be done well.

The concept of online learning refers to e-learning. Elearning was created for distance learning. Distance learning separates students and teachers by distance and time. In addition, this learning is a form of innovation in the world of education since the existence of internet technology. Computer programs are more varied with the use of the internet so that distance learning can be done in a multi-way manner [6].

Gilber and Jones (2001) and Michael (2013) explain the abbreviation "E" in e-learning to mean electronic. Elearning is all forms of learning activities that utilize electronic media to help humans learn. This opinion has a broad meaning because it emphasizes electronic based. Meanwhile, Hartley (2001), Rosenberg (2001), and 
Kamarga (2001) explain that e-learning is the use of internet technology and network computers in the human learning process. This opinion is significantly more specific because the emphasis on Internet-based [6]

Som Naidu (2006) explains that the e-learning refers to learning online, which means the deliberate use information and communication technology nerwork in the teaching and learning process [7]. In particular, Tafiardi (2005) [4] stated that e-learning is a learning model in digital format. The implementation of e-learning can be done in direct and indirect ways. Implemented directly means that when the instructor gives lessons, students can immediately hear. Meanwhile, the implementation through indirect means, for example, instructor message recorded before use.

The main characteristics of e-learning are using computers and the internet. Other characteristics, namely (a) the presence of content or learning material that is relevant to the learning objectives; (b) using appropriate learning methods; (c) using learning media in various formats such as text, visuals, videos, multimedia; (d) can occur synchronously or asynchronously [7].

In e-learning, applications are needed to support the learning process. Various e-learning support applications can be accessed by students such as google applications, messenger applications, web-based technology, and other supporting applications (dropbox, remote desktop) [6]. Currently, the government also officially references several educational applications in the implementation of learning from home, namely: Rumah Belajar, Meja Kita, Icando, IndonesiaX, Google for Education, Microsoft Office 365, Quipper School, Teacher Room, Sekolahmu, Zenius, and Cisco Webex [8].

\section{METHOD}

This research is descriptive research. Descriptive research is research that is intended to investigate circumstances, conditions, or other things and does not change, add, or manipulate the object under study [9]. The data collection technique was carried out by studying the literature. The data collected comes from various articles, books and other documents. The articles collected with internet access and search the data by focusing on three topics, namely the perception students in online learning during a pandemic Covid-19 applications in learning online during a pandemic Covid-19, and learning strategies online. Furthermore, the data are grouped and analyzed to obtain information about the implementation of online learning, applications used, and learning strategies.

\section{RESULT AND DISCUSSION 3.1. Implementation of Learning Online In The Pandemic Covid-19}

The implementation of learning in Indonesia has undergone a transformation from face-to-face learning to online learning. This was carried out in connection with circular number 4 of 2020 concerning the implementation of education policies in the emergency period of the spread of Coronavirus Disease (Covid-19) by the Minister of Education and Culture on March 24, 2020 [1]. The regulation stipulates several matters regarding education policies, including the cancellation of the implementation of the National Examination and the learning process carried out from home. Learning of the house is done by learning online or remotely to provide meaningful learning for students, focused on life skills education, learning that varies according to your interests and conditions of each student. Further, the restriction rules school activities strengthened by Minister of health number 9 in 2020 on the Large-Scale Sosial Restriction [10].

Towards entering the new academic year, the spread of Covid-19 has not been fully resolved. The Minister of Education and Culture issues guidelines for implementing curriculum in educational units under special conditions. Conditions intestine means a disaster that is determined by the central governments and local governments. In this special condition, assessment of learning is still carried out on the principle of being valid, reliable, fair, flexible, authentic, and integrated. Education units can choose one of the curricula set by the ministry of education, namely continuing to use the 2013 national curriculum, using the emergency curriculum, and simplifying the curriculum independently [11].

According to a decree with the Minister of Education and Culture, the Minister of Health, Minister of Religious Affairs, and Minister of the Interior on the Implementation of Free Education in the academic year 2020/2021 and 2020/2021 academic years during a Pandemic Corona Virus Disease 2019 (Covid-19), face-to-face learning may be carried out in the green zone and yellow zone category based on the mapping carried out by the national task force handling Covid-19. Meanwhile, for the orange and red zone category areas it is prohibited to carry out face-toface learning in educational units and to continue carrying out learning activities from home [12] .

Learning from home during a pandemic Covid-19 was carried out in two ways, namely online and offline. The implementation of learning from home has dynamics. Various challenges, obstacles, and strengths influence each other in the implementation of learning from home. Moreover, in carrying out online learning, students, teachers, and parents are faced with a digital world which has not been familiar in everyday life.

Implementation online learning for Pandemic Covid-19 was considered effective and ineffective. Several studies have shown that online learning can be carried out effectively $[8,13,14,15,16,17,18,19,20]$. Online learning can be done anytime and anywhere using a cellphone, android, laptop, or computer [5]. Online learning is considered to be more relaxed, fun, flexible, efficient, short, practical, fast, safe, easy, time-saving, and energy efficient [18]. In online learning, Android or smartphones are mostly used by students [19]. In addition, student learning motivation in online learning is also considered to be higher because it uses learning applications such as google classroom, whatsapp group, youtube, instragram, and zoom $[17,20]$. The learning motivation of female students is higher than male students [22]. 
Some studies suggest that learning online is less effectively implemented during a pandemic Covid-19 [22, $23,24]$. In lessons that are practical subjects such as Physical Education Sports and Healt, learning online can not be done because of lack of communication between students and teachers [13]. Online learning also affects students psychologically [5] such as easily bored and bored [23] and students always feel anxious [26]. In addition, many students prefer to study in school because they can interact directly [25].

The dynamics of learning online during a pandemic Covid-19 are found. Barriers to online learning, especially the increase in internet quota costs, are a burden, especially for parents and honorary teachers $[5,8,16,18$, $19,25,26]$ and internet access that is not supports $[5,19$, 20, 24, 25, 27, 28]. Many students do not have smartphones that support learning [19, 22, 27, 28]. Schools and each teacher give many tasks so that students' assignments often pile up [20, 24, 25, 26]. During online learning, communication between students, students and teachers, teachers and parents is reduced $[18,19,26]$. The mastery of technology possessed by students, teachers, and parents is low [27], 27, 28].

Home conditions or atmosphere that are less conducive to be a challenge while studying from home [15, 19, 24]. This makes it difficult for students to do assignments [24, 25]. In addition, learning methods and models are less varied [5, 19]. It can be assumed, the heavy work done by teachers is because teachers did not have a limit on working hours during this Covid-19 pandemic [18, 26]. At all times the teacher must communicate with parents, other teachers, and the principal.

It is undeniable, apart from these obstacles, through online learning, students acquire broad knowledge [19]. Parents were closer to children during the Covid-19 pandemic because they always supervised children's learning [18]. The extraordinary achievement in children is the development of character that is creative, innovative, independent, disciplined, and active and parents and teachers also know and are able to operate technology [18, 19, 27].

\subsection{Learning Online Effective During Pandemic Covid-19}

During learning online conducted during the pandemic Covid-19 in Indonesia, some teachers and education observers have contributed their thoughts so that learning can take place effectively. PKM TEAM of the College of Economics and Trade [30] conducted a socialization on the use of the zoom meeting application and google classroom. The socialization was given to teachers of SD 17 Mata Air Kota Padang. Teachers can also take advantage of applications suggested by the government in online learning. There are 12 platforms that were inaugurated for use by the Ministry of Education and Culture because they are considered easy to access, such as: Rumah Belajar, Meja Kita, Icando, IndonesiaX, Google for Education, Microsoft Office 365, Quipper School, Ruang Guru, Sekolahmu, Zenius, Cisco Webex [8]. In addition, there are also applications that have been tested by several researchers and are considered effective in online learning, namely Google Classroom [14,17,20]; Google Form [14], Quizizz [14], Edmodo [15], Whatsapp $[8,20]$, Youtube, Instagram, Zoom [21], as well as Schoology portal and Vlog [2]. Based on the survey conducted by the Institute of Economic Social Digital (ISED) [28], the use of applications that are popular in online learning during a pandemic Covid-19 is Whatsapp (34\%), Google Classroom (18\%), and Zoom (18\%). Whatsapp is popular in online learning because its use is familiar and some people have downloaded it on their respective mobile devices.

Methods in learning also need to be considered in online learning. Project-based learning can maximize online learning [32]. Bell (2010) [33] argues that project-based learning can motivate students independently to find information by utilizing various sources. Online learning can also be done with the inqury-based student centered learning method [31]. Learning centered on students. In its implementation, the teacher sends materials and assignments via the Whatsapp Group. Students try independently to find the answer to every assignment of teachers to take advantage of a variety of learning resources.

In psychology, students are subject to the heaviest pressure in the learning experience online during a pandemic Covid-19. For that, students must learn independently. In doing the assignments students must be disciplined immediately carry out the assignments given by the teacher. If there are problems in learning, students can discuss with teachers or friends. Students must have positive thoughts in prayer, passionate, and perform other activities such as watching, listening to music, sleeping, eating, and exercise [26].

The teacher is a source of knowledge and motivator for students. Changing patterns of learning in the digital age requires teachers to develop models, innovation, evaluation of the digital media [34], and increasing competence in the management of learning online [35]. The teacher made learning online se how effective and does not burden the students with tasks [29]. The teacher provides the material before giving the assignment which is accompanied by task work steps [21]. Teachers make use of internet technology that uses the smallest internet bandwidth, for example by turning off the camera during a video conference [28].

Schools and teachers must understand again the implementation of learning that has been regulated in the circular of the Minister of Education and Culture number 4 of 2020. Online learning is carried out by providing meaningful experiences for students, without being burdened with demands for curriculum achievement, focused on life skills education, assigning assignments according to interests and the condition of students with attention to facilities at home, and schools and teachers provide qualitative feedback [1]. In addition, it should also be understood that in times of pandemic Covid-19, the school can also simplify the curriculum independently [36]. Expansion of technology platform support that can be utilized in online learning needs to be followed up quickly 
[19]. This effort has been made by the Government through the Ministry of Education and Culture to strengthen cooperation with the private sector and the Ministry of Communications and Information Technology in utilizing technology learning platforms, such as Rumah Belajar, Kelas Pintar, Quipper School, Ruang Guru, and Zenius. Support was also given by the commission was to prioritize Rumah Belajar to cooperate with TVRI and RRI for learning online can be affordable evenly throughout Indonesia [37].

We deserve to follow online learning practices that are applied abroad. According to Snelling and Fingal (2020) [18], the International Society for Technology in Education (ISTE) in the United States identify the practices carried out by teachers for teaching during the pandemic Covid-19. First, prepare and practice. At this stage, there are five things that must be considered, namely paying attention to digital equity, practicing, giving clear expectations to teachers and parents, taking time to plan learning concepts, and completing personal facilities and infrastructure. Paying attention to digital completeness or school teachers can do to assess the needs of a device that will help the student learning. The teacher also has to ensure that the digital devices owned by students can accommodate the applications needed. Teachers need to practice if the online learning model is their first experience. Teachers must quickly master technology so that communication can run smoothly with students. Schools and related parties must make plans and guidelines regarding the implementation of online learning that will be carried out.

Second, implementation. At this stage several things must be considered, namely setting a daily schedule, providing strong learning with small activities, independent learning design, paying attention to emotional conditions, and choosing tools that are fixed and appropriately used in online learning. It is very important to set a daily schedule because a full day in front of a screen is not effective, especially for children who share devices with other family members. Learning activities must have targets to be achieved. After achieving the target, provide feedback or comments on student assignments. Independent learning designs are needed so that children do not need parents to do assignments. Emotional conditions can be maintained by taking regular breaks, taking time to exercise and socializing with family. Teachers also have to limit the applications used so that students and parents can follow learning well. Ethics when conducting video conferencing must also be considered, for example, the problem of clothing. Through online learning, it emphasizes us to be responsible in utilizing online media.

\section{CONCLUSION}

Learning from home is the right policy for the Minister of Education and Culture in an effort to prevent the spread of Covid-19. Online learning is an alternative option so that the teaching and learning process can be carried out over a distance. The dynamics of online learning influenced the pattern of education that occurred during the Covid-19 pandemic. Implementation of learning online during the pandemic Covid-19 get res pounds of positive from the students .

Resistance and challenges can not be covered in the implementation of learning online. The biggest obstacle to online learning is the internet connection which is not yet evenly distributed throughout Indonesia. Online learning costs a lot because learning depends on internet quotas. Parents and teachers, especially honorarium teachers, have not been able to meet the quota financing to access learning. Facilities and infrastructure, such as smartphones, are serious obstacles to online learning for students who come from weak economies.

Online learning challenges teachers, students and parents to master technology. Teachers must exercise develop competence to be creative, active and innovative in finding methods and media that appeal to students. In addition, teachers must be proficient in applying various learning platforms such as Classroom, Zoom, Google Form, Edmodo, Quizizz and so on. For students, online learning fosters an independent, creative, disciplined, and active character. Online learning provides its own meaning for parents when accompanying children in learning so that closeness and harmonious relationships are created.

Schools and government should seek various solutions for the implementation of learning online during the pandemic Covid-19 even for the future can be performed well. Teacher competence determines the success of online learning. Teachers have the awareness and readiness to face this digital era. Schools and the government also made a breakthrough innovative technology literacy for teachers. The adequacy of the availability of infrastructure in online learning needs to be fulfilled evenly so that education reaches all corners of Indonesia.

\section{ACKNOWLEDGMENT}

I was finally able to finish this paper thanks to the support of various parties. I am very grateful to my supervisor, Dr. Abdurahman, M. Pd. for motivation, inspiration, and wise guidance. I also thank my beloved family who never stopped supporting me. This paper is far from perfect, for that contructive criticism and sugestions are expected.

\section{REFERENCES}

[1] K. K. Pendidikan, "Mendikbud Terbitkan SE tentang Pelaksanaan Pendidikan dalam Masa Darurat Covid19," Kemdikbud, 2020.

[2] A. Jayul, E. Irwanto, "Model Pembelajaran Daring Sebagai Alternatif Proses Kegiatan Belajar Pendidikan Jasmani di Tengah Pandemi Covid-19," Jurnal Pendidikan Kesehatan Rekreasi, 2020, 6(2): 190-199.

[3] Y. Ariyana, A. Pudjiastuti, R. Bestary, Zamromi, "Buku Pegangan Pembelajaran Berorientasi pada Keterampilan Berpikir Tingkat Tinggi: Program Peningkatan Kompetensi Pembelajaran Berbasis Zonasi," Direktorat Jendral Guru dan Tenaga 
Kependidikan, 2018.

[4] D. S. Ibrahim, S. P. Suardiman, "Pengaruh Penggunaan E-Learning terhadap Motivasi dan Prestasi Belajar Matematika Siswa SD Negeri Tahunan Yogyakarta," Jurnal Prima Edukasia, 2014, 2(1): 66-79.

[5] A. P. Satrianingrum, I. Prasetyo, "Persepsi Guru Dampak Pandemi Covid-19 terhadap Pelaksanaan Pembelajaran Daring di PAUD," Jurnal Obsesi: Jurnal Pendidikan Anak Usia Dini, 5(1): 633-640.

[6] R. Wahyuningtyas, D., Makmur, E-learning Teori dan Aplikasi. 2017.

[7] H. Prawiradilaga, D. S. Ariani, D., Handoko, Mozaik Teknologi Pendidikan: E-learning. 2016.

[8] A. R. H. Diana Novita, "Plus Minus Penggunaan Aplikasi-Aplikasi Pembelajaran Daring Selama Pandemi Covid-19," Unimed Medan, 2020.

[9] S. Arikunto, Prosedur Penelitian : Suatu Pendekatan Praktik (Edisi Revisi). 2012.

[10] D. V. Putsanra, "Arti PSBB yang Dibuat untuk Cegah Penyebaran Corona di Indonesia," Tirto.id. 2020.

[11] Pengelola web Kemdikbud, "Kemendikbud Terbitkan Pedoman Penyelenggaraan Belajar dari Rumah," Jakarta, 28 Mei 2020, 2020.

[12] Kemendikbud, "SKB Empat Menteri," 2020.

[13] A. Kurniasari, F. S. P. Pribowo, D. A. Putra, "Analisis Keefektivan Pelaksanaan Belajar dari Rumah (BDR) Selama Pandemi Covid-19," Jurnal Review Pendidik Dasar, 2020, 6(3).

[14] B. Mulatsih, "Penerapan Apikasi Google Clasroom, Google Form, dan Quizizz dalam Pembelajaran Kimia di Masa Pandemi Covid-19," Ideaguru: Jurnal Karya Ilmiah Guru, 2020, 5(1).

[15] I. Oktaviani, I. Waspada, N. Budiawati, "Penerapan Media Pembelajaran E-Learning Berbasis Edmodo Pada Pembelajaran Daring Saat Pandemi Covid-19 (Ditinjau dari Persepsi Siswa)," Jurnal IKA: Ikatatan Alumni PGSD UNARS, 2020, 8(1): 68-78.

[16] R. Meidawati, Sobron A.N, Bayu, "Persepsi Siswa dalam Studi Pengaruh Daring Learning terhadap Minat Belajar IPA," Scaffolding: Jurnal Pendidikan Islam dan Multikulturalisme, 2019, 1(2): 30-38.

[17] P. U. Zulfah, "Peningkatan Motivasi Belajar Menggunakan ' Google Classroom' di Tengah Pandemi Covid-19 Pada Peserta Didik Kelas XI IPS 4 SMAN 1 Bangkinang Kota," Jurnal on Education, 2020, 2(3): 275-285.

[18] P. Wahyono, H. Husamah, A. S. Budi, "Guru Profesional di Masa Pandemi Covid-19: Review Implementasi, Tantangan, dan Solusi Pembelajaran Daring," Jurnal Pendidikan Profesi Guru, 2020, 1(1): 51-65.

[19] S. Zuriati, B. Briando, "Persepsi Siswa Terhadap Pembelajaran Online di Masa Pandemi Pada Sekolah Menengah Atas Negeri Empat Tanjungpinang," 2020.

[20] W. A. F. Dewi, "Dampak Covid-19 Terhadap Implementasi Pembelajaran Daring di Sekolah Dasar," Edukatif : Jurnal Ilmu Pendidikan, 2020,
2(1): 55-61.

[21] Mustakim, "Efektivitas Pembelajaran Daring Menggunakan Media Online Selama Pandemi Covid19 Pada Mata Pelajaran Matematika t," Al Asma: Journal Islamic Education, 2020, 2(1): 1-2.

[22] A. Cahyani, I. D. Listiana, S. P. D. Larasati, "Motivasi Belajar Siswa SMA pada Pembelajaran Daring di Masa Pandemi Covid-19," IQ (Ilmu Alqur'an) Jurnal Pendidikan Islam, 2020, 3(1): 123140.

[23] H. Putria, L. H. Maula, D. A. Uswatun, "Analisis Proses pembelajaran Dalam Jaringan (DARING) Masa Pandemi COVID-19 pada Guru Sekolah Dasar," Jurnal Basicedu, 2020, 4(4): 861-872.

[24] P. Komarudin, "Persepsi Siswa Terhadap Pembelajaran Daring Mata Pelajaran Pendidikan Jasmani Olahraga dan Kesehatan pada Masa Pandemi Covid-19," Majalah Ilmiah Olahraga, 2020, 26(2): 56-66.

[25] P. Megawanti, E. Megawati, S. Nurkhafifah, "Persepsi Peserta Didik terhadap PJJ pada Masa Pandemi COVID-19," Jurnal Ilmiah Kependidikan, 2020, 7(2): 75-82.

[26] D. H. Oktawirawan, "Faktor Pemicu Kecemasan Siswa dalam Melakukan Pembelajaran Daring di Masa Pandemi Covid-19," Jurnal Ilmiah Universitas Batanghari Jambi, 2020, 20(2): 541-544.

[27] A. Purwanto et al., "Studi Eksploratif Dampak Pandemi COVID-19 Terhadap Proses Pembelajaran Online di Sekolah Dasar," EduPsyCouns, 2020, 2(1):1-13.

[28] U. F. R. Rahmawaty, "Pendidikan di Tengah di Masa Covid-19," Institude of Sosial Economic and Digital. 2020.

[29] R. H. S. Aji, "Dampak Covid-19 pada Pendidikan di Indonesia," Jurnal Sosial Budaya Syar-i, 2020, 7(5):395-402.

[30] S. Suhery, T. J. Putra, J. Jasmalinda, "Sosialisasi Penggunaan Aplikasi Zoom Meeting dan Goggle Classroom Pada Guru di SDN 17 Mata Air Padang Selatan," Jurnal Inovasi Pendidikan, 2020, 1(3): 129132.

[31] R. Fitriyani, R. Fernandes, "Pelaksanaan Student Centered Learning Berbasis Online Pada Pembelajaran Sosiologi Siswa Kelas X IPS SMA Negeri 4 Bukittinggi Masa Pandemi Covid-19," Jurnal Sikola, 2020, 2(1): 8-18.

[32] K. Arizona, Z. Abidin, R. Rumansyah, "Pembelajaran Online Berbasis Proyek Salah Satu Solusi Kegiatan Belajar Mengajar di Tengah Pandemi Covid-19," Jurnal Ilmiah Profesi Pendidikan, 2020, 5(1): 64-70.

[33] A. Habók, J. Nagy, "In-Service Teachers' Perceptions of Project-Based Learning," Springerplus, 2016, 5(8): 2-14.

[34] T. N. Azis, "Strategi Pembelajaran Era Digital," Annual Conference Islamic Educatin and Social Sains (ACIEDSS 2019), 2019.

[35] F. N. Arifa, "Tantangan Pelaksanaan Kebijakan Belajar Dari Rumah Dalam Masa Darurat Covid-19," 
Info Singkat: Kajian Singkat Terhadap Isu Aktual dan Strategi, 2020, 12(7): 13-18.

[36] S. T. P. Covid-19, "Penyesuaian Kebijakan Pembelajaran di Masa Pandemi Covid-19," Csis Comment., 2020.

[37] N. Arnesti, A. Hamid, "Penggunaan Media Pembelajaran Online - Offline dan Komunikasi Interpersonal Terhadap Hasil Belajar Bahasa Inggris," Jurnal Teknolologi Informasi \& Komunikasi dalam Pendidikan, 2015, 2(1): 85-99. 